\title{
A Conceptual Framework for A Corporate Finance Valuation Method
}

\author{
Wai Leong Soon (Corresponding author) \\ Azman Hashim International Business School, Universiti Teknologi Malaysia \\ Level 10, Menara Razak, Jalan Sultan Yahya Petra, 54100 Kuala Lumpur, Malaysia \\ Tel: 60-122-818-248Ｅ-mail: soonwaileong@gmail.com
}

\begin{abstract}
Rohaida Basiruddin
Azman Hashim International Business School, Universiti Teknologi Malaysia

Level 10, Menara Razak, Jalan Sultan Yahya Petra, 54100 Kuala Lumpur, Malaysia

E-mail: rohaida@ibs.utm.my
\end{abstract}

Received: Oct. 2, 2018 Accepted: Oct. 16, $2018 \quad$ Published: December 11, 2018

doi:10.5296/bms.v9i2.13731ＵRL: https://doi.org/10.5296/bms.v9i2.13731

\begin{abstract}
The Ohlson Model and its variants have been widely studied by researchers for value relevance of accounting information. It has been used to predict share prices and to assess the fundamental value of a firm. The original Ohlson Model does not clearly define the non-accounting information variables as the linear information dynamics variables. In relation to that, we propose a conceptual framework that includes the Piotroski F-Score, trading liquidity and systematic risk as the linear information dynamics variables in the Ohlson Model to improve prediction of share prices and forecasting capacity of the Ohlson Model or to better evaluate the fundamental value of the firm. Literature pertaining to Ohlson Model, Piotroski F-Score, trading liquidity and systematic risk are analysed, compared and synthesized to fulfil the research objective. It is expected that this paper will motivate future researchers to conduct more research in this field.
\end{abstract}

Keywords: Share price, valuation, finance, accounting, value relevance

JEL Classification: G11; G17; G31 


\section{Introduction}

The capital marketplace such as the stock exchange creates a situation where both principals and agents derive benefits. Investors can increase their wealth by investing and/or trading in shares whilst firms are able to access capital for the purpose of business expansion. The determining factor of these transactions is the price of the securities, which has been mutually consented between both parties. Therefore, it is vital for all parties to understand the valuation of the firm, so that they are able to make a rational investment decision. "In accounting research, value relevance means that something has a material impact on the value of organisation" (Rautiainen et al., 2017, p21). The study of value relevance which represents concurrent testing of the relevance and reliability of accounting information has shown that accounting information are significant factors in the evaluation of the firm and bear a correlation to firms' share prices and market values (Hassan et al., 2016; Shittu et al., 2016; Lyle et al., 2013; Dahmash and Qabajeh, 2012; Duran et al., 2007; Wu et al., 2005; Barth et al., 2001).

Ohlson (1995) has improved on the residual income model by converting the dividend discount model, which is commonly used in the evaluation of a firm's share price, to be based on the historical accounting information. Ohlson (1995) proposed a model to evaluate a firm's share price in terms of its current equity value, current abnormal earnings, current dividends paid, and "other information" variables that may influence the abnormal earnings in the subsequent financial period. Due to the vague description of the "other information" variables in Ohlson Model, researchers and academics have adopted and studied other non-accounting information variables such as corporate governance variables (Brugni et al., 2013; Lee and Lin, 2010), operating cash flow per share (Shittu et al., 2016; Duran et al., 2007), expected cash flows and/or shocks to discount rates (Vuolteenaho, 2002), financial reporting standards, firm size (measured in assets or revenue), trading volume, positive and negative income and degree of intangible-intensity (Hassan et al., 2016; Shittu et al., 2016; Wu et al., 2005), Piotroski F-Score (Duran et al., 2014), expected net period abnormal earnings (Lyle et al., 2013), leverage and managed earnings (Hassan et al., 2016) and systematic risk (Lyle et al., 2013; Wu and Wang, 2008).

However, there is a dearth of research that jointly investigates the effects of the Piotroski F-Score, trading liquidity and systematic risk as "other information" variables in Ohlson Model to predict and forecast share prices or to value the firm. This paper aims to propose an extension to Duran et al. (2014)'s research by including trading liquidity and systematic risk into the Ohlson Model and to propose a conceptual framework that will serve as a guide for practitioners in making better business decisions. The study had also taken cognisance of the signalling theory and legitimacy theory adopted in value relevance research (Gitahi et al., 2018). Therefore, we believe that the findings will be of interest to other researchers and the paper is expected to contribute to existing literature.

In developing the conceptual framework, works of literature on Ohlson Model, Piotroski F-Score, trading liquidity and systematic risk were reviewed and analysed, compared and 
synthesized to fulfil the aim of this paper. The outline of the review is as follows: Section 2 consists of literature review and conceptual design; Section 3 presents the conclusion, implications, and significance of the study; and finally, Section 4 sets out the limitations and future research directions.

\section{Literature Review and Conceptual Design}

\subsection{Theoretical Framework}

Kumari and Sekhar Mishra (2017) stated that the Ohlson Model is a milestone study in accounting research because the Ohlson Model enables researchers to study stock prices and accounting numbers systematically. Many empirical studies have also supported the case for Ohlson Model. Bernard (1995) noted that Ohlson Model guides researchers in studying the relationship between accounting data and firms' value. Ohlson (1995) provides a useful guide to researchers for conceptualising a theoretical framework and benchmark on how the market reacts to accounting data and other information. Another advantage of the Ohlson Model is that it defines a conceptual framework that enables researchers to relate the market value of the firm with the past and future financial information of the firm, i.e. with current and future expected net income, with the equity book value, and with dividends (Gama et al. ,2017).

According to Kumari and Sekhar Mishra (2017) and Lyle et al. (2013), the Ohlson Model is based on three crucial assumptions. The first assumption of the Ohlson Model states that a firm's cost of capital is equal to the risk-free rate in a risk-neutral world where beliefs are homogenous. The second assumption defines the clean surplus relation of the current year's book value as the sum of the preceding year's book value add profit after taxation after deducting dividends paid to shareholders. The third and final assumption in the Ohlson Model is referred to as linear information dynamics (LID) variables. Based on the three assumptions, the Residual Income Valuation (RIV) model (also known to be equivalent to the DDM) forms an integral part of the Ohlson Model as it was derived from the combination of RIV and LID. In this regard, Lo and Lys (2000) explained that the testing of the Ohlson Model represents a joint test of the RIV and LID models.

In order to allow investors to predict future abnormal earnings by estimating the future reported earnings and dividends in the model, Ohlson (1995) suggested the LID whereby additional variables are to be added to the model in the form of additional assumptions. The assumptions allow firm's market value to be expressed in terms of observable variables. When these forecasting dynamics are combined with the RIV model, Ohlson (1995) showed that the valuation of a firm can be expressed as a linear combination of book value, abnormal earnings and "other information". For simplicity, the Ohlson Model can be expressed in the valuation function:

$$
\begin{gathered}
\mathrm{MV}_{\mathrm{t}}=\mathrm{B}_{\mathrm{t}}+\alpha_{1} \mathrm{X}_{\mathrm{t}}^{\mathrm{a}}+\beta_{1} \mathrm{~V}_{\mathrm{t}} \\
\mathrm{X}_{\mathrm{t}}^{\mathrm{a}}=\mathrm{X}_{\mathrm{t}}-\mathrm{rB}_{\mathrm{t}-1}
\end{gathered}
$$

where, 
$\mathrm{MV}_{\mathrm{t}}$ : Market value of the firm at time $\mathrm{t}$

$\mathrm{B}_{\mathrm{t}} \quad$ : Book value of the firm at time $t$

$\mathrm{x}_{\mathrm{t}}^{\mathrm{a}}$ : Abnormal earnings of the firm at time $\mathrm{t}$

$\mathrm{xt}_{\mathrm{t}}$ : Earnings of the firm at time $\mathrm{t}$

$\mathrm{R}$ : Risk-free rate at time $\mathrm{t}$

$\mathrm{B}_{\mathrm{t}-1} \quad$ : Book value of the firm at time $\mathrm{t}-1$

$\mathrm{Vt} \quad$ : Other information at time $\mathrm{t}$

$\alpha_{1}: \frac{\omega}{(1+r-\omega)}$

$\beta_{1}: \frac{(1+r)}{(1+r-\omega)(1+r-\gamma)}$

$\omega \quad$ : persistence parameter for abnormal earnings $(0 \leq \omega \leq 1)$

$\gamma \quad$ : persistence parameter for "other information” $(0 \leq \gamma \leq 1)$

Based on the above, Ohlson's contribution to capital market research can be summarised into three parts. First, Ohlson (1995) revives the use of residual income in valuation research by proposing information dynamics linking RIV with testable propositions. Second, LID provides an avenue to link the DDM to observable accounting variables. Third, the model provides a framework to elaborate, discern and understand the different ad-hoc past valuation approaches (for example, it discusses whether changes in earnings or earnings levels are appropriate indicators in explaining firms' share prices or the costs of capital (expected return)).

\subsection{The Accounting Information of Ohlson Model}

Based on the review of past researches, the Ohlson Model had been previously studied and value relevance of accounting information has been found by past researchers including, Ahmed and Boutheina (2017), Hassan et al. (2016), Shittu et al. (2016), Omokhudu and Ibadin (2015), Duran et al. (2014) and Lyle et al. (2013).

Accordingly, two hypotheses in relation to the accounting information are formulated as follows:

Hypothesis 1: Book values of firms positively affect firms’ share prices.

Hypothesis 2: Earnings of firms positively affect firms' share prices.

\subsection{The Non-Accounting Information of Ohlson Model}

Duran et al. (2014) explained that the Ohlson Model provides the theoretical framework for researchers while "other information” variables are uniquely adapted to make up the practical aspects of the Ohlson Model. Considering that there is a dearth of research that examines the relationship jointly between Piotroski F-Score, trading liquidity, systematic risk and firms' share prices, the following hypotheses shall be formulated as follows:

Hypothesis 3: Piotroski F-Score positively affects firms’ share prices. 
Hypothesis 4: Trading liquidity positively affects firms' share prices.

Hypothesis 5: Systematic risk negatively affects firms’ share prices.

The proposed conceptual framework based on the hypotheses developed is illustrated in Figure 1.

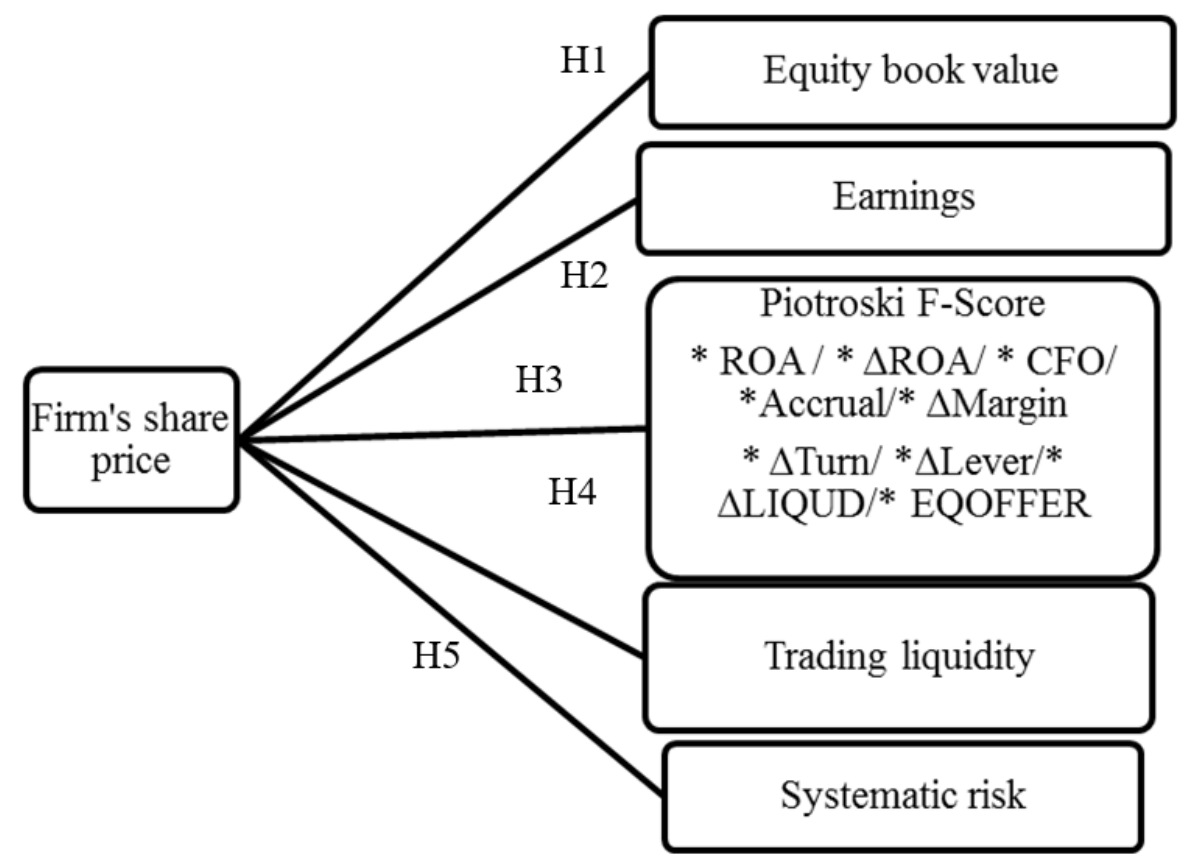

Figure 1. Conceptual framework

\subsubsection{Literature Review on Piotroski F-Score}

The use of analysts' forecast was supported by Ahmed and Boutheina (2017) whereby it was found that the accuracy of the analysts forecasting increase over time when the analysts understand the business of the firms that they are analysing and/or understand the demands of users/ readers of analysts' reports better, and the participants in the stock exchange have been increasing their reliance on the earnings forecast of analysts. However, the risk of forecast bias is present when using analysts' forecast as claimed by Scherbina (2004). In view of the possible risks of forecast bias, we propose to adopt the Piotroski F-Score researched by Duran et al. (2014).

The Piotroski F-Score is a holistic measure of profitability, leverage, liquidity, source of funds as well as efficiency based on 9 different criteria. Piotroski (2000) prepared the scale to evaluate the financial performance of the firm based on historical financial data to differentiate firms with strong prospects or winners (with the highest score: 9) from firms with weak prospects or losers (with the lowest score: 0 ). Although the Piotroski F-Score is calculated using the historical financial data, the score provides evidence on the trend on the performance of the firm (Duran et al., 2014) and it has been claimed by Choi and Sias (2012) that Piotroski F-Score can forecast future returns and future demand by sophisticated 
investors. In this regard, selecting stocks based on accounting information can influence investment portfolio performance (Turtle and Wang, 2017; Duran et al., 2014).

Recent studies on the Piotroski F-Score as a criterion of stock selection have been conducted by Hyde (2014) for emerging markets, Agrawal (2015) in India as well as the developed countries by Patari et al. (2018) and Turtle and Wang (2017). On this matter, the use of Piotroski F-Score in security analysis whereby investors invest in securities of firms with high F-Score earn a significant premium over securities from firms with a low F-Score and should be used as a supplementary selection criterion to value stocks (Patari et al., 2018; Sareewiwathana and Janin, 2017; Hyde, 2014). Turtle and Wang (2017) who examined the relationships between firms' return and Piotroski F-Score in the United States had also included six risk factors, namely market risk, size effects, high-minus-low factor, momentum factor, robust-minus-weak factor and conservative-minus-aggressive factor which form the Fama-French five factor models proposed by Fama and French (2015) have concluded that in the event of high information uncertainty or market optimism, there will be a substantial portion of observed mispricing. However, firms' share prices will adjust albeit gradually Turtle and Wang (2017).

Premised on the above, the Piotroski F-Score as a LID variable may be more appropriate compared to the use of forecasts' earnings based on analyst consensus used by Lyle et al. (2013), Spilioti (2015) and Ahmed and Boutheina (2017). Furthermore, the Piotroski F-Score which is based on historical financial information supports Damodaran (2012)'s views that the true value of the firm can be attributed to its financial fundamentals.

\subsubsection{Literature Review on Trading Liquidity}

Investors prefer greater liquidity and will expect a liquidity premium in the expected return on their investment when holding less liquid assets (Acharya and Pedersen, 2005). In other words, securities bearing identical risk profiles should have the same expected return (Huang et al., 2014). Emshwiller (as cited in Beedles, 1991) suggested that improving trading liquidity will reduce investors' required return and henceforth, firms' cost of capital decrease accordingly. Butler et al. (2005) found that liquidity in the stock market is an important determinant of the cost of raising external capital for firms based on a sample of 2,387 seasoned equity offerings in the United States from the year 1993 to the year 2000. They found that investment banks' fees, a fund-raising expense, for more liquid stocks are significantly lower and concluded that improving the market liquidity of the firms' securities can reduce firms' cost of raising capital. In addition, Saad and Samet (2017) found that liquidity risks and liquidity volatility affect the implied cost of capital based on an investigation on 14,808 stocks from 52 countries and surmised that shareholders will require extra premium as an incentive for holding illiquid stocks.

In review of past literature on Ohlson Model, this paper has taken note that Wu et al. (2005) had studied the annual trading volume of firms listed on the Shanghai and Shenzhen stock exchanges, whereby A-Shares refers to shares of companies with large market capitalisation 
and B-Shares to shares of companies with small market capitalisation. However, the findings were inconclusive vis-a-vis the value relevance of trading volume to share prices. This may be due to the use of trading volume instead of Lo and Wang (2000)'s aggregate turnover which is the sum of trading volume divided by the number of issued shares (Bogdan and Ivanovic, 2012).

Premised on the above, the paper noted that liquidity has a vital role in the pricing of securities and proposes that Lo and Wang (2000)'s aggregate turnover as a LID variable in the Ohlson Model.

\subsubsection{Literature Review on Systematic Risk}

Advancement had been made on the works of Ohlson (1995) and Feltham and Ohlson (1995) to address issues regarding risk aversion, imperfect LID, term structure of the cost of capital and so on (Konchitcki, 2016). Konchitcki (2016) proposed to extend the accounting theoretical modelling to include economics data at the macro-level. "This new research area focuses on addressing real-life world problems using the added value that accounting can bring to various macro-level topics that are at the forefront of the academic and professional discussions. Examples include inflation, inequality, the housing market, recessions, GDP, business cycles, the banking system, and national accounting” (Konchitcki, 2016, p.27) However, Wooi and Brooks (2015) explained that there is no general agreement in the systematic risk determinants in macroeconomic literature but the exchange rate, interest rates, and multiple global economic fundamentals were the emphasis in prior studies.

Systematic risk in the economy should be considered and accounted for in the analyses of share prices. Lyle et al. (2013) extended the Ohlson Model to include systematic risk in view of the original Ohlson Model which are based on the assumptions of risk neutrality and that interest rates are not stochastic and flat. The traditional model such as the capital assets pricing model (CAPM) is used to calculate the firm's expected return does not have a clear relationship with accounting information based on the CAPM formula. Therefore, the incorporation of the systematic risk variable is an improvement to the models proposed by Ohlson (1995) and Feltham and Ohlson (1999) as it has been found that stock returns were robustly predicted when aggregate risk was included as a variable (Lyle et al., 2013; Ang et al., 2006).

Premised on the review of past literature on Ohlson Model, the study found that systematic risk in Ohlson Model was studied by Lyle et al. (2013) and Wu and Wang (2008). Lyle et al. (2013) adopted VIX as the empirical proxy for economy-wide risk and found strong negative associations between changes in economy-wide risk and future stock returns. "VIX is an index derived from S\&P 500 options prices designed to estimate the market's expected 30-day volatility.” (Kownatzki, 2016, p39). On the other hand, Wu and Wang (2008) approached systematic risk by adopting the volatilities of the consumer price index, the interest rate, the exchange rate and real economic growth rate as the LIDs in the Ohlson Model to represent the systematic risk in their studies of firms in the United States and 
Taiwan. Wu and Wang (2008) found the following: significant negative effects on Taiwanese firms' stock prices for volatility of commodity prices, fluctuating interest rates show significant but opposite directions in the United States (negative) and Taiwanese (positive) markets, fluctuating exchange rates exert a more significant impact on the Taiwanese (positive) firms' stock prices than of the United States firms' stock prices, and volatility of real economic growth rates displays a significant positive effect on stock price in Taiwan's market. The study of Wu and Wang (2008) using many different variables suggested that the nation's central bank's policy and intervention on the foreign exchange and interest rate can influence the performance of the stock market.

We have also noted that there is a solution to VIX as proposed by Fadzil et al (2017) in their article on "Cross-sectional volatility index as a proxy for the VIX in an Asian market" by constructing of a VIX-styled index that is depending on the price of calls and puts option. Although they have proposed the cross-sectional volatility (CSV) index, they have only recommended it to be applied to the Japanese market. Furthermore, practitioners may not be able to construct a CSV index for other markets that have no or less liquid derivatives market as CSV index is dependent on put and call option prices.

Considering that there is no definite proxy for systematic risk, we propose the use of exchange rate as a proxy for systematic risk for countries outside the United States in the absence of an equivalent VIX measure used by Lyle et al. (2013) as changes in exchange rate can influence the performance of the stock market.

\section{Conclusions, Implications and Significance}

A conceptual framework based on the theoretical work of Ohlson (1995) has been proposed in this study. The conceptual framework follows the approach of Duran et al. (2014) in proposing a framework to examine firms' share prices in an Ohlson Model with the Piotroski F-Score as a LID variable. The conceptual framework proposed to extend the LID variables to include the trading liquidity and systematic risk. The literature review provides theoretical and empirical guidance on predicting and forecasting share prices and to value firms using the Ohlson Model based on accounting information, Piotroski F-Score, trading liquidity and systematic risk. It can be assumed that the accounting information, Piotroski F-score, trading liquidity and systematic risk are vital in asset pricing and cost of capital measurement. Nevertheless, there is a need for further research on these variables as well as how these variables can be combined to form a robust model for predicting and forecasting share prices and to value firms.

The study also aims to add to the pool of existing material or knowledge which will pave the way for further research on related subject matters. In this paper, we attempted to incorporate the practical aspects of the Piotroski F-Score, trading liquidity and systematic risk into a singular model. The conceptual framework serves as a guide to enable practitioners whose knowledge of the relationship between the Piotroski F-Score, trading liquidity, systematic risk and firms' share prices is an important input into investment analysis, corporate finance 
valuation, and portfolio investments. Lastly, firms will be able to appreciate the importance of the Piotroski F-Score as a financial tool to evaluate the past and the present financial performance of a firm as it could serve as a proxy for the future performance of firms' securities in the capital market (Duran et al., 2014).

\section{Limitations and Future Research Directions}

The primary limitation of this study is that the facts are limited to papers reviewed and analysed. This paper offers the opportunity to refine and validate the concepts that emerged based on our inductive analysis. Therefore, as part of future research directions, the research scope for this conceptual model can be extended with respect to theory or adapt an appropriate research methodology to examine it empirically in order to make this a more robust model for predicting and forecasting share prices or for valuation purpose.

\section{References}

Acharya, V. V., \& Pedersen, L. H. (2005). Asset pricing with liquidity risk. Journal of Financial Economics, 77(2), 375-410. https://doi.org/10.1016/j.jfineco.2004.06.007

Ahmed, B., Boutheina, R., \& McMillan, D. (2017). The accuracy of financial analysts' earnings forecasts and the Tunisian market reliance with time. Cogent Economics \& Finance, 5(1), 1- 14. https://doi.org/10.1080/23322039.2017.1345186

Ang, A., Hodrick, R., Xing, Y., \& Zhang, X. (2006). The cross-section of volatility and expected returns. Journal of Finance, 61(1), 259-299. https://doi.org/10.1111/j.1540-6261.2006.00836.x

Barth, M. E., Beaver, W. H., \& Landsman, W. R. (2001). The value relevance literature for financial accounting standard setting: another view. Journal of Accounting and Economics, 31(1-3), 77-104. https://doi.org/10.1016/S0165-4101(01)00019-2

Beedles, W. L. (1991). Size, Liquidity, and the Cost of Equity. Journal of Small Business Finance, 1(1), 29-44. Retrieved from https://digitalcommons.pepperdine.edu/jef/vol1/iss1/4

Bernard, V. L. (1995). The Feltham-Ohlson Framework: Implications for Empiricists. Contemporary Accounting Research, 11(2), 733-747. https://doi.org/10.1111/j.1911-3846.1995.tb00463.x

Bogdan, S., Bareša, S., \& Ivanovic, S. (2012). Measuring Liquidity on Stock Market: Impact on Liquidity Ratio. Tourism and Hospitality Management, 18(2), 183-193. Retrieved from https://hrcak.srce.hr/93935

Bolibok, P. M. (2014). Application of the Ohlson Model for Testing the Value Relevance of Accounting Data in the Polish Banking Sector. ZESZYTY NAUKOWE UNIWERSYTETU SZCZECIŃSKIEGO, 802, 463-471. Retrieved from http://www.wneiz.pl/nauka_wneiz/frfu/65-2014/FRFU-65-463.pdf

Brugni, T. V., Dalmacio, F. Z., Bortolon, P., \& Neto, A. S. (2013). The Ohlson Residual 
Income Valuation Model for Valuing Corporate Governance In Brazil: Some Empirical Evidence. In conference: 36th Annual Congress of European Accounting Association, Paris, France: European Accounting Association. https://doi.org/10.13140/2.1.4217.6647

Butler, A. W., Grullon, G., \& Weston, J. P. (2005). Stock Market Liquidity and the Cost of Issuing Equity. Journal of Financial and Quantitative Analysis, 40(2), 331-348. https://doi.org/10.1017/S0022109000002337

Choi, N. Y., \& Sias, R. W. (2015). Why Does Financial Strength Forecast Stock Returns? Evidence from Subsequent Demand by Institutional Investors. The Review of Financial Studies, 25(5), 1550-1587. https://doi.org/10.1093/rfs/hhs001

Damodaran, A. (2012). Investment valuation: Tools and techniques for determining the value of any asset. United States: John Wiley and Sons Ltd.

Dahmash, F. N., \& Qabajeh, M. (2012). Value Relevance of Ohlson Model with Jordanian Data. Interdisciplinary Journal of Contemporary Research in Business, 3(11), 551-560. Retrieved from https://www.uop.edu.jo/download/research/members/551-560\%20-\%20Copy.pdf

Duran R. V., Valdés A. L., \& Ramírez, C. E. C. (2014). Effectiveness of corporate finance valuation methods: Piotroski score in an Ohlson model: the case of Mexico. Journal of Economics Finance and Administrative Science, 19(37), 104-107. https://doi.org/10.1016/j.jefas.2014.04.003

Duran R. V., Valdes A. L., \& Herrera H. V. (2007). Value Relevance of the Ohlson model with Mexican data. Revista de Contaduria y Administracion, 1(223, UNAM), 33-52. Retrieved from

http://www.scielo.org.mx/scielo.php?script=sci_arttext\&pid=S0186-10422007000300003

Fama, E. F., \& French, K. R. (2015). A five-factor asset pricing model. Journal of Financial Economics, 116(1), 1-22. https://doi.org/10.1016/j.jfineco.2014.10.010

Fadzil, F. J., O’Hara, J. G., \& Ng, W. L. (2017). Cross-sectional volatility index as a proxy for the VIX in an Asian market. Cogent Economics \& Finance, 5(1), 1-15. https://doi.org/10.1080/23322039.2017.1364011

Feltham, G., \& Ohlson, J (1995). Valuation and clean surplus accounting for operating and financial activities. Contemporary Accounting Research, 11(2), 689-731. https://doi.org/10.1111/j.1911-3846.1995.tb00462.x

Gama, A. O. M., Segura, L. S., \& Filho, M. A. F. M. (2017). The Ohlson and Feltham Ohlson Models. Equity valuation and negative earnings - the Case Of The Dot.Com Bubble (pp. 19-41). Singapore, Springer.

Gitahi, J., Nasieku, T., \& Memba, F. (2018). Corporate Social Responsibility Disclosure and the Value Relevance of Annual Reports for Listed Banks in Kenya. European Scientific 
Journal, 14(4), 329- 349. https://doi.org/10.19044/esj.2018.v14n4p\%25p

Hassan, M. S., Saleh, N., Rahman, A. F., \& Shukor, Z. (2016). Underinvestment and Value Relevance of Earnings Management. Jurnal Pengurusan, 46, 99-113. Retrieved from http://journalarticle.ukm.my/10801/1/9290-43009-1-PB.pdf

Huang, J.-Z., Helwege, J., \& Wang, Y. (2014). Liquidity effects in corporate bond spreads. Journal of Banking and Finance, 45, 105-116. https://doi.org/10.1016/j.jbankfin.2013.08.018

Hyde, C. (2014). An Emerging Markets Analysis of The Piotroski F-Score. JASSA The Finsia Journal of Applied Finance, 2, 23-28.

Konchitchki Y. (2016). Accounting Valuation and Cost of Capital Dynamics: Theoretical and Empirical Macroeconomic Aspects: Discussion of Callen. ABACUS, 52(1), 26-34. https://doi.org/10.1111/abac.12071

Kownatzki, C. (2016). How Good is the VIX as a Predictor of Market Risk?. Journal of Accounting and Finance, 16(6), 39-60. Retrieved from http://www.na-businesspress.com/JAF/KownatzkiC_Web16_6_.pdf

Kumari, P., \& SekharMishra, C. (2017). A Literature Review on Ohlson (1995). Asian Journal of Finance \& Accounting, 9(2). https://doi.org/10.5296/ajfa.v9i2.11492

Lee S. C., \& Lin C. T. (2010). An accounting-based valuation approach to valuing corporate governance in Taiwan. Journal of Contemporary Accounting \& Economics, 6(2), 47-60. https://doi.org/10.1016/j.jcae.2010.09.002

Lee, S. C., Chen, J. L., \& Tsa, M. S. (2014). An Empirical Investigation of the Ohlson Model-A Panel Cointegration Approach. Australasian Accounting, Business and Finance Journal, 8(2), 35-51. https://doi.org/10.14453/aabfj.v8i2.4

Lo, A. W., \& Wang, J. W. (2000). Trading Volume: Definitions, Data Analysis, and Implications of Portfolio Theory. Review of Financial Studies, 13(2), 257-300. https://doi.org/10.3386/w7625

Lo, K., \& Lys, T. (2000). The Ohlson Model: Contribution to Valuation Theory, Limitations, and Empirical Applications. Journal of Accounting, Auditing \& Finance, 15(3), 337-367. https://doi.org/10.1177/0148558X0001500311

Lyle, M. R., Callen, J. L., \& Elliott, R. J. (2013). Dynamic risk, accounting-based valuation and firm fundamentals. Review of Accounting Studies, 18(4), 899-929. https://doi.org/10.1007/s11142-013-9227-x

Ohlson, J. (1995). Earnings, book values, and dividends in equity valuation. Contemporary Accounting Review, 11(2), 661-687. https://doi.org/10.1111/j.1911-3846.1995.tb00461.x

Omokhudu, O. O., \& Ibadin, P. O. (2015). The Value Relevance of Accounting Information: Evidence from Nigeria. Accounting and Finance Research, 4(3), 20-30. 
https://doi.org/10.5430/afr.v4n3p20

Patari E. J., Leivo T. H., Hulkkonen, J., \& Honkapuro, J. V. S. (2018). Enhancement of value investing strategies based on financial statement variables: the German evidence. Review of Quantitative Finance $\quad \& \quad$ Accounting, 513-845. https://doi.org/10.1007/s11156-017-0689-y

Piotroski, J. D. (2000). Value investing: The use of historical financial statement information to separate winners from losers. Journal of Accounting Research, 38(3), 1-41. https://dx.doi.org/ 10.2307/2672906

Rautiainen, A., Sippola, K., \& Mättö, T. (2017). Perspectives on Relevance: The Relevance Test in the Constructive Research Approach. Management Accounting Research, 34, 19-29. https://doi.org/10.1016/j.mar.2016.07.001

Saad, M., \& Samet, A. (2017). Liquidity and the implied cost of equity capital. Journal of International Financial Markets, Institutions and Money, 51, 15-38. https://doi.org/10.1016/j.intfin.2017.08.007

Sareewiwatthana, P., \& Janin, P. (2017). Tests of quantitative investing strategies of famous investors: case of Thailand. Investment Management and Financial Innovations, 14(3), 218-226. https://doi.org/10.1016/j.intfin.2017.08.007

Scherbina, A. (2004). Analyst Disagreement, Forecast Bias and Stock Returns (Working paper 05-003). HBS Publishing, United States: Harvard Business School. Retrieved from http://citeseerx.ist.psu.edu/viewdoc/download?doi=10.1.1.200.9017\&rep=rep1\&type=pdf

Shittu, I., Ahmad, A. C., \& Ishak, Z. (2016). Equity Valuation Multiples and Stock Returns: Evidence from Malaysian Listed Firms. In International Conference on Accounting Studies (ICAS) 2016, Langkawi, Malaysia: International Conference on Accounting Studies. Retrieved from http://icas.my/download/icas_2016/249-253-131.pdf

Spilioti, S. N. (2010). The incorporation of risk into the clean-surplus valuation model: evidence from UK stocks. Investment Management and Financial Innovations, 7(3), 82-88. Retrieved from https://businessperspectives.org/images/pdf/applications/publishing/templates/article/assets/3 534/imfi_en_2010_03_Spilioti.pdf

Turtle, H. J., \& Wang, K. (2017). The Value in Fundamental Accounting Information. Journal of Financial Research, 4(1), 113-140. https://dx.doi.org/10.1111/jfir.12119

Vuolteenaho (2002). What Drives Firm-Level Stock Returns?. The Journal of Finance, 57(1), 233-264. https://dx.doi.org/10.1111/1540-6261.00421

Wooi H. C., \& Brooks, R. D. (2015). The Components of Systematic Risk and Their Determinants in The Malaysian Equity Market. Asian Academy of Management Journal of Accounting and Finance, 11(2), 151-176. Retrieved from 


\section{Macrothink}

http://web.usm.my/journal/aamjaf/vol\%2011-2-2015/aamjaf110215_07.pdf

Wu, P. C., \& Wang, C. J. (2008). The Effect of Systematic Risk on Equity Valuation: An Extended Application of the Ohlson Equity Valuation Model. Journal of Humanities and Social Sciences, 4(1), 69-81. $\quad$ Retrieved from http://libwri.nhu.edu.tw:8081/Ejournal/AL02040107.pdf

Wu, S. H., Koo, M., \& Kao, T. (2005). Comparing the value relevance of accounting information in China: Standard and factors Effects. Retrieved from https://business.illinois.edu/zimmerman/wp-content/uploads/sites/56/2015/08/Wu-Koo-Kao.p $\mathrm{df}$

\section{Copyright}

Copyright for this article is retained by the author(s), with first publication rights granted to the journal.

This is an open-access article distributed under the terms and conditions of the Creative Commons Attribution license (http://creativecommons.org/licenses/by/4.0/). 